\title{
INTERFACE METACOGNIÇÃO E SEMIÓTICA PARA A LEITURA DE TEXTOS SINCRÉTICOS
}

\author{
Ana Paula Teixeira de Amorin Rodrigues ${ }^{1}$ \\ Valdenildo dos Santos ${ }^{2}$
}

\section{RESUMO}

Por meio de pesquisa realizada junto a 59 alunos do $8^{\circ}$ ano de duas escolas públicas de Três Lagoas, Mato Grosso do Sul, descobriu-se que o gênero textual preferido foram as Histórias em Quadrinhos. Portanto, foi selecionada uma HQ da turma da Mônica, cujo autor Maurício de Sousa faz uma crítica à economia do país e pedido que os alunos escrevessem uma primeira interpretação de forma livre sobre o que entenderam do texto. O material coletado serviu de base para a comprov ação das hipóteses de que havia problemas de falta de motiv ação, leitura crítica e escrita de acordo com a norma padrão. Diante do quadro, foi elaborado um plano de ação com exercícios sobre metacognição (FLAVEL, 1979, SOLÉ, 1998), atividades inspiradas em sequência didática (DOLZ, NOVERRAZ \& SCHNEUWLY, 2004), que contemplaram os nív eis de leituras propostos pela semiótica francesa (GREIMAS E SEUS DISCÍPULOS), num processo de correção-interativ a (RUIZ, 2015) e reescrita da escrita para a escrita (MARCUSCHI, 2010). São apresentados, portanto, aqui, a utilização da semiótica sincrética e sua importância como ferramenta para a abertura da percepção quanto ao sentido de enunciados que acoplam a linguagem verbal e não verbal, parte englobante de dissertação de mestrado defendida em 2016.

Palavras-chave: Leitura Crítica, Semiótica Sincrética, Histórias em Quadrinhos.

\footnotetext{
1 Mestre em Linguagem e Letramentos pela UFMS - Universidade Federal de Mato Grosso do Sul, Programa de Pós-Graduação em Linguagens e Letramentos. Três Lagoas - MS - Brasil. Email: anapaula_amorin@hotmail.com.

2 Doutor em Letras, Filologia e Linguística Portuguesa (Semiótica) pela UNESP, Universidade Estadual Paulista "Júlio de Mesquita Filho", Assis, São Paulo, atual Professor adjunto IV da UFMS - Universidade Federal de Mato Grosso do Sul - Pós-Graduação Linguagens e Letramentos, Três Lagoas, - MS - Brasil e Pós-doutorando em Linguagens e Cultura pela Purdue University, Indiana, Estados Unidos. E-mail: vdossant@purdue.edu, valdenildo.santos@ufms.br. Phone (804) 859-7180.
} 


\title{
INTERFACE METACOGNITION AND SEMIOTICS FOR THE READING OF SYNCRETIC TEXTS
}

\begin{abstract}
Through a research conducted with 59 students from the 8th grade of two public schools in Três Lagoas, Mato Grosso do Sul, it was found that the preferred textual genre was Comic Books. Therefore, a comic from the class of Mônica was selected, whose author Maurício de Sousa criticizes the economy of the country and asked that the students write a first interpretation of free form on what they understood of the text. The material collected served as a basis for the verification of the hypothesis that there were problems of lack of motivation, critical reading and writing according to the standard norm. In the framew ork of this framework, an action plan with exercises on metacognition (FLAVEL, 1979, SOLÉ, 1998), activities inspired by a didactic sequence (DOLZ, NOVERRAZ \& SCHNEUWLY, 2004) was elaborated, which contemplated the levels of readings proposed by French semiotics GREIMAS AND ITS DISCIPLES), in a process of corrective-interactive (RUIZ, 2015) and rewriting of writing for writing (MARCUSCHI, 2010). Therefore, the use of syncretic semiotics and its importance as a tool for the opening of the perception about the meaning of statements that couple verbal and nonv erbal language, an integral part of a master dissertation defended in 2016 , are presented here.
\end{abstract}

Keywords: Critical Reading. Syncretic semiotics. Comic books

\section{INTERFACE METACOGNICIÓN Y SEMIÓTICA PARA LA LECTURA DE TEXTOS SINCRÉTICOS}

\section{RESUMEN}

Por medio de una encuesta realizada junto a 59 alumnos del $8^{\circ}$ año de dos escuelas públicas de Três Lagoas, Mato Grosso do Sul, se descubrió que el género textual preferido fueron las Historietas. Por lo tanto, fue seleccionada una $\mathrm{H}$ de la clase de Mónica, cuyo autor Maurício de Sousa hace una crítica a la economía del país y pedido que los alumnos escribieran una primera interpretación de forma libre sobre lo que entendieron del texto. El material recolectado sirvió de base para la comprobación de las hipótesis de que había problemas de falta de motivación, lectura crítica y escrita de acuerdo con la norma estándar. En el marco del cuadro, se elaboró un plan de acción con ejercicios sobre metacognición (FLAVEL, 1979, SOLÉ, 1998), actividades inspiradas en secuencia didáctica (DOLZ, NOVERRAZ \& SCHNEUWLY, 2004), que contemplaron los niveles de lecturas propuestos por la semiótica francesa, en un proceso de corrección-interactiva (RUIZ, 2015) y reescritura de la escritura para la escritura (MARCUSCHI, 2010). Se presenta, por lo tanto, aquí, la utilización de la semiótica sincrética y su importancia como herramienta para la apertura de la percepción en cuanto al sentido de enunciados que acoplan el lenguaje verbal y no verbal, parte englobante de disertación de maestría defendida en 2016.

Palabras clave: Lectura crítica. Semiótica sincrética. Historietas. 


\section{ISSN 2237-9460}

\section{INTRODUÇÃO}

Ao atuarmos como professores de Língua Portuguesa por muitos anos verificamos que os estudantes possuem algum conhecimento prévio que os auxilia na interpretação de textos verbais, mas não o fazem de maneira sistemática e consciente, especialmente em relação aos textos de natureza sincrética. Pensando nisso, surgiram as hipóteses de que com uma proposta que trouxesse como meta as atividades metacognitivas, proporcionando aos alunos a autoconsciência de seus processos de aprendizagem, direcionados para a leitura e escrita de textos somadas à aquisição dos níveis possíveis de leitura de textos apregoados pela semiótica da Escola de Paris e a teoria da figuratividade de Nícia Ribas D'Ávila poderíamos reverter este quadro disfórico da falta de motivação, abertura da percepção do sentido e de uma escrit a mais coerente do texto.

Embora saibamos que essa semiótica está presente em livros didáticos, como aqueles de Platão e Fiorin, não era conhecida no universo de 59 alunos pesquisados em duas escolas de Três Lagoas, no interior do Mato Grosso do Sul, na divisa com São Paulo. Diante do quadro e com a consciência de que a semiótica da Escola de Paris não vai resolver todos os problemas de leitura e escrita em sala de aula, mas que pode amenizá-los é que surge este trabalho de pesquisa, cujos objetivos principais estão no preenchimento das faltas encontradas, como a indiferença à leitura, a falta de estímulos à leitura crítica e escrita de textos com base em estratégias para a leitura, em especial, de enunciados de caráter não verbal e sincréticos, como as Histórias em Quadrinhos.

Deste modo, são examinadas aqui parte de uma coleta de 56 redações praticadas por 28 alunos aos quais foram apresentadas atividades de leitura semiótica inspiradas e adaptadas a partir das sequências didáticas tradicionais voltadas para a leitura e consequente escrita de textos, cujos resultados apresentamos a partir de agora. 


\section{A METACOGNIÇÃO NA SALA DE AULA}

L.S. Vygotsky $(1997,1998)$ afirma que cabe ao professor apresentar aos alunos estratégias e ferramentas possíveis para a abstração e os conceitos básicos de teorias que venham desencadear o autoconhecimento de suas atividades. Neste sentido, ensinar conceito e aplicabilidade da metacognição é um primeiro passo para a aquisição de processos reguladores próprios, do encontro de melhores formas de leitura e solução de problemas por meio do pensar sobre o pensar, a meta memória.

Segundo René Descartes é preciso pensar para existir. Marcamos nossa existência, deste ponto de vista, pelo exercício do pensamento. É esse "pensar" que nos interessa aqui, como objeto modal da autonomia, do ato de ler e escrever, do saber sobre o ser no mundo. Para ser no mundo é preciso que desenvolvamos a criticidade e aprofundemos nossa percepção de tudo que nos cerca. É, igualmente, em como adquirir esse saber que estamos interessados.

\section{COGNIÇÃO, METACOGNIÇÃO E SOCIOCOGNIÇÃO}

A "aquisição do conhecimento", o "conhecimento", a "percepção" é o que define etimologicamente o termo cognição, (1873), do latim cognitioonis (CUNHA, 1997, p. 193). O "Arcade Dictionary of Word Origins" de John Ayto (1990, p. 123) já explicava a origem do termo como vindo do verbo latino cognit que produziu o substantivo cognitio, fonte da palavra "cognition", em inglês, "the act or experience of knowing, including consciousness of things and judgement about them" (LOGMAN, 1992, p. 239).

Como vemos, esta segunda definição amplia o raio de alcance da palavra, posto que se refere ao ato ou experiência do saber, incluindo a consciência das coisas e seu julgamento. Entramos, deste modo, numa relação próxima entre os termos cognição e metacognição, posto que o segundo não aparece nos dicionários (pelo menos naqueles que foram aqui pesquisados e que constam da nossa referência) e foi usado pela primeira 
vez por John H. Flavell (1979), ao realizar pesquisas sobre a metamemória infantil, ou seja, o saber e controle que as crianças tinham do processamento de sua memória.

O prefixo grego "meta", como Cunha o apresenta, "expressa as ideias de comunidade ou participação, mistura ou intermediação e sucessão" (1997, p. 516) conduzindo-nos ao pensar no conceito de sociocognição, a junção de socius do Latim, "associado, companheiro, aliado", repercutindo a ideia de agregar, unir, reunir, associar. Logo, há uma aproximação entre os três termos que, neste artigo, quer que desaguem em autonomia, o gerenciamento próprio dos afazeres, da expressão cognitiva, da aquisição do conhecimento, do ato de ler e escrever de maneira crítica, num pleno exercício de cidadania.

\section{AS PESQUISAS DE FLAVELL E BROWN}

Flavell descobriu que ao aumentar a quantidade e qualidade do conhecimento, da consciência da criança sobre como se processa a aquisição do saber, o que ele vai chamar de "children's metacognitive knowledge" e monitorar as habilidades através de um treinamento sistemático "may be feasible as well as desirable" (1979, p. 906).

Além de Flavell, a estudiosa da psicologia do desenvolvimento Ann Brown (1943-1999) também estava interessada no assunto, mas foi com Kreutzer e Leonard que Flavell (1975) entrevistou crianças na pré-escola, séries $1^{a}, 3^{a}$, e $5^{a}$ a fim de determinar seu conhecimento sobre 0 funcionamento de sua memória.

A metodologia utilizada pelos estudiosos envolvia perguntas abertas sobre situações baseadas em sugestões, usando o saber de uma pessoa, a tarefa e várias estratégias que influenciavam a memória. 
Um exemplo descrito por Linda Baker (2009)33 consistia em perguntar as crianças como elas poderiam ter certeza de se lembrar de levar seus "skates" para a escola no dia seguinte de aula e como se lembrariam de um número de telefone e se seria mais fácil ou mais difícil se lembrarem de uma lista de palavras que já tinham estudado. As respostas revelaram que mesmo as crianças menores tinham algum conhecimento do funcionamento de sua memória, mas eram as crianças mais velhas que apresentaram maiores percepções.

Brown utilizava fotos de objetos simples, materiais acadêmicos e prosa, conforme suas publicações "Knowing when, where, and how to remember: A problem of metacognition" (1978) e "Metacognitive development and Reading" (1980). É, portanto, na segunda metade da década de 70 que os estudos sobre metacognição ganham corpo.

As pesquisas de Brown nos idos de 1970 sobre as habilidades das crianças de acessar sua própria leitura para serem testadas quanto à sua capacidade de se lembrarem das experiências ou informações recebidas no uso de material de apoio didático pedagógico, como fotos de objetos comuns, resultaram com a maior naturalidade em investigações sobre o papel da metacognição nos estudos de material acadêmico e na compreensão de prosa. É na década de 80, todavia, que Brown apresenta a metacognição à comunidade de pesquisadores da leitura e contribui de forma decisiva na linha ativa de inquisição de domínio específico do assunto.

É preciso salientar, no entanto, que embora seja Flavell que utilize o termo "metacognição" pela primeira vez e se reconheça a importância de suas pesquisas, das pesquisas de Brown nas décadas de 70 e 80, já existiam pesquisadores interessados no assunto no início do século passado,

\footnotetext{
3 Artigo disponível online https://cie581fall2009.wikispaces.com/file/view/Baker+ +Metacognition.pdf com o título "Metacognition", publicado em dezembro de 2009 visitado em 23 de Junho de 2016.
} 
documentando a importância das atividades de monitoramento e regulação dos processos de compreensão da leitura.

$\mathrm{Na}$ década de sessenta, por exemplo, surgem os pesquisadores da memória que estudavam as sensações, as emoções, os sentimentos das crianças ao fazerem o monitoramento de seu pensamento, fazendo surgir os modelos de processamento da informação da década de 70 como os sistemas de controle executivos que regulam os processos cognitivos básicos.

Além destes pesquisadores, o psicólogo soviético Lev Vygotsky (18961934) e o psicólogo suiço Jean Piaget (1896-1980) já incluíam em suas teorias sobre o pensamento das crianças os processos metacognitivos. Vygotsky, por exemplo, observou que as crianças desenvolviam a capacidade de auto regulação de suas atividades por meio da interação com outras crianças que possuíam mais conhecimento que elas.

Dentre as anotações de Vygotsky podemos citar: a) assunção da responsabilidade do progresso do monitoramento; b) o estabelecimento de metas; c) o planejamento das atividades e d) a alocação da atenção, o que chamou de processos executivos nos quais a responsabilidade da execução do processo de leitura, do aprendizado, é dada de forma gradual, tornando os alunos capazes de regular suas próprias atividades cognitivas.

Desta forma, a marca indicativa de excelência da metacognição surge no início do ano 2000, como sendo a transição entre ser regulado pelos outros e ter seu próprio regulamento, se fazer a própria regulação das atividades.

Foi Piaget quem descobriu e teorizou que os semelhantes, os colegas numa sala de aula, por exemplo, desafiam os pensamentos uns dos outros e, por assim fazerem, desenvolvem sua cognição. Ao levar uma criança a pensar em seu próprio pensamento a induzimos à prática da metacognição.

Desta forma, na verdade, é a teoria vigotskiana que fundamenta as intervenções em sala de aula nos dias atuais que começam com as instruções explícitas por parte do professor, seguidas da prática dirigida e 
modelada das estratégias metacognitivas e cognitivas, com a liberação gradual da responsabilidade aos alunos.

O professor é, assim, o sujeito destinador que delega ao aluno a responsabilidade do processo do aprendizado, ou seja, da leitura, no caso, de um texto, fazendo o próprio monitoramento do passo a passo que chegará ao término do processo, momento da autoavaliação e do repensar das atividades com base no que funcionou melhor durante o processo para a solução dos problemas encontrados.

ESQUEMA DA SEQUÊNCIA DIDÁTICA
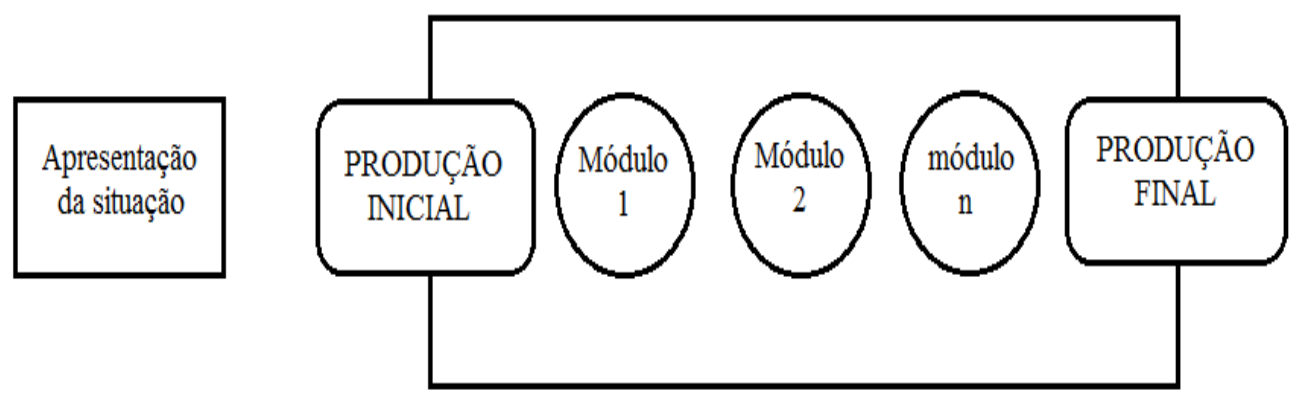

Fonte: DOLZ, NOVERRAZ \& SCHNEUWLY, 2004, p. 83.

São, portanto, os trabalhos de Flavell, Brown, Palincsar e tantos outros mais recentes, inclusive no Brasil (LEFFA, 1996, SILVEIRA, 2005, GERALDI, 2010 dentre outros) que refletem as imagens passadistas da teoria de Piaget, que revelam que as discussões, os debates e a colaboração ajudam os estudantes a monitorar sua própria compreensão e construir novas capacidades estratégicas.

\section{A SEQUÊNCIA DIDÁTICA}

Para realizarmos atividades que mostram os três níveis possíveis de leitura do texto fomos inspirados pelo trabalho de Joaquim Dolz, Michèle Noverraz e Bernard Schneuwly, os quais falam de um ensino da expressão oral e escrita por meio de sequências didáticas. Do ponto de vista do 
despertar da motivação, serviu de inspiração a ênfase dos Parâmetros Curriculares Nacionais (PCNs), que definem S/Q com base em Dolz e Schneuwly como "um conjunto de atividades escolares organizadas, de maneira sistemática, em torno de um gênero textual oral ou escrito" (DOLZ, NOVERRAZ \& SCHNEUWLY, 2004, p. 82).

Se o trabalho com gêneros tanto orais como escritos deve refletir o meio em que o sujeito está inserido, pois existem várias situações onde deverão usar a linguagem oral como em conversas familiares, negociações e outras escritas que podem ser exemplificadas por cartas, contos ou mesmo dissertações, então cada uma das situações de comunicação exige certo tipo de linguagem.

Dolz e Schneuwly sugerem uma regularidade no trabalho escolar, ressaltando que "O trabalho escolar será realizado, evidentemente, sobre gêneros que o aluno não domina ou o faz de maneira insuficiente; sobre aqueles dificilmente acessiveis, espontaneamente, pela maioria dos alunos; e sobre gêneros públicos e não privados" (2004, p. 83). É por meio destas atividades, por assim dizer, que pretendemos fazer com que os alunos pesquisados tivessem acesso às práticas de linguagem novas ou dificilmente domináveis, como os processos metacognitivos e semióticos.

Desta forma seguimos o esquema canônico da S/Q representada pelos autores para realizarmos as atividades de leituras semióticas por níveis.

Em seguida, pedimos aos alunos que fizessem uma nova leitura do texto já examinado uma primeira vez a fim de verificarmos se houve ou não mudança ou aprofundamento da sua visão quanto ao sentido.

\section{A RETEXTUALIZAÇÃO DO TEXTO ESCRITO PARA O TEXTO ESCRITO}

Quando Luiz Antônio Marcuschi fala da escrita para a escrita ele refere-se ao resumo. Na liberdade concedida pelo próprio linguista quanto à sua proposta, o texto escrito aqui (textualização) é o antes da S/D e o outro texto escrito (retextualiação) é a segunda interpretação do mesmo 
enunciado e não apenas um resumo, conforme vemos no quadro de possibilidades que apresenta:

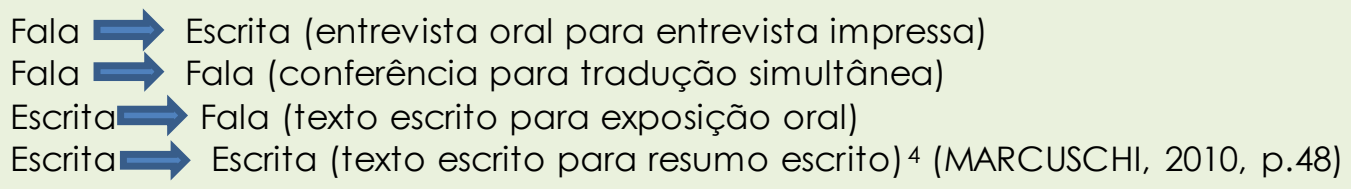

Consideramos que o objetivo da retextualização era verificar o antes e o depois da S/D, se houve ou não ampliação da percepção do sentido no interior do texto, tendo o mesmo sujeito para o texto original, primeiro e segunda escrita, sem uma preocupação com o gênero com o qual iriam se expressar, deixando livre a escolha.

\section{A CORREÇÃO DAS REDAÇÕES}

Para o processo de correção contamos com as sugestões de Eliana Donaio Ruiz em seu livro "Como corrigir redações na escola" (2015) que mostra a correção-interativa dentre outros procedimentos sob três perspectivas, ou seja, a correção indicativa, que cuida das palavras, das frases e dos períodos que apresentam erros ou são pouco claros, (RUIZ, 2015, p. 36), e verifica os deslizes ortográficos e lexicais, a correção resolutiva que trata de corrigir todos os erros, reescrevendo palavras, frases e períodos inteiros e a correção classificatória que surge com a opinião do professor (RUIZ, 2015, p. 41).

Depois das atividades em sala de aula procedemos as atividades sugeridas por Ruiz a fim de que tomassem conhecimento de suas próprias dificuldades e corrigissem, eles mesmos, suas falhas, rumo à autonomia de seu fazer pragmático e cognitivo.

\section{AS HQS E O PROCESSO DE GERAÇÃO DE ESTÍMULO E MOTIVAÇÃO}

Foi Eisner (1999) quem chamou as HQs de "arte sequencial" que tiveram início nas pinturas rupestres e se consolidaram nos jornais a partir do

\footnotetext{
4 Ver mais especificamente em MARCUSCHI, 2010, p. 49.
} 
século XX, onde estão até hoje, oriundas que foram dos gibis ou almanaques, chegando ao jornal onde ganharam mais força de popularização em meio aos jovens e adultos, alcançando sua especificidade.

Mendonça (2010) afirma que as HQs, embora apareçam em alguns livros didáticos, avaliações externas como os vestibulares e o Enem, não fazem parte do cânon dos textos trabalhados pela escola. Sua leitura é fácil, mas há aquelas que "demandam estratégias de leitura sofisticadas, além de um alto grau de conhecimento prévio" (2010, p. 214). Ele defende a função didática das HQs no sentido de instruir ou persuadir, apesar de serem incorporadas a partir da década de 90 nos livros didáticos de português como atividades não muito importantes do tipo "Divirta-se", "Só para ler", sendo raro quando aparecem como texto central da unidade didática.

Ele sugere que levemos os alunos a perceberem as estratégias discursivas utilizadas por seus produtores e que podemos estudá-las ainda como "elementos icônicos como a forma e o contorno dos balões (para a fala, o medo, o sonho, o pesadelo, o pensamento etc.)" (2010, p. 220). Além destes aspectos, devemos conduzir os alunos à percepção do "tamanho e o tipo das letras (para sentimentos como a raiva, o grito, o amor, a indiferença etc.), os sinais usados no lugar das letras (para os palavrões, para línguas estrangeiras ou extraterrestres), a disposição do texto (sem parágrafos ou travessões)" (2010, p. 220). Por estas razões Mendonça defende o estudo relacional dos marcadores tipográficos e o sentido do texto, como "material rico para o entendimento dos múltiplos usos da linguagem" (2010, p. 220) atrelado às atividades de criação de $H Q$ s pelos alunos, a transformação de contos, por exemplo, em HQs, como resultado de um possível diálogo com a literatura. 


\section{A SEMIÓTICA DE GREIMAS E A TEORIA DA FIGURATIVIDADE VISUAL}

A semiótica greimasiana se consolidou em um instrumento importante para a análise do discurso, oriunda de um projeto científico, segundo o próprio Greimas (GREIMAS \& COURTÉS, 2013, p.448) que trata da significação de textos, sejam esses verbais, não verbais ou sincréticos.

O percurso gerativo do sentido é traçado a partir de um produtor textual que veleja de uma estrutura profunda ao ato da enunciação, passando por uma estrutura menos profunda, até chegar ao enunciado, como simplificado por Francisco Platão Savioli \& José Luiz Fiorin (2007) de maneira didática, em níveis de leitura.

Platão e Fiorin "bebem" na fonte do dicionário de Greimas e Courtés onde vemos o esquema de Greimas como Estruturas Narrativas, SemioNarrativas e Discursivas (2013, p. 232). Destacam Platão e Fiorin que "a partir da observação dos dados concretos da superfície, pode-se chegar à compreensão de significados mais abstratos, que dão unidade e organização ao texto" (2007, p. 35) e chamam estas estruturas de superficial, intermediária e profunda.

Este modelo nos inspira à criação de estratégias de leituras por níveis em que os alunos podem explorar na superfície do texto os significados mais concretos e diversificados, como as categorias semânticas, o que se afirma e o que se nega e o que é eufórico e disfórico.

No segundo nível de leitura, o narrativo, chamado por Platão e Fiorin de estrutura intermediária os alunos podem encontrar os valores com os quais os diferentes sujeitos entram em acordo ou desacordo, assinam um contrato fiduciário ou não e na estrutura profunda ocorrem os significados mais abstratos e mais simples (PLATÃO \& FIORIN, 2007, p. 37).

Diana Luz Pessoa de Barros (2001, p.15) chama tais estruturas de nível fundamental, nível narrativo e nível discursivo que, segundo a autora, podem ser analisados separadamente, mas, para o sentido completo do texto, devem-se analisar as relações entre os três níveis. 
Para se chegar ao sentido de um texto, o leitor analista parte do percurso gerativo do sentido que se articula num processo "que vai do mais simples ao mais complexo, do mais abstrato ao mais concreto" (GREIMAS \& COURTÉS, 2013, p. 232).

Greimas define o percurso narrativo que, grosso modo, seria a presença em todo discurso de um Destinador e um Destinatário, sendo que este apresenta um nível imanente e aquele um nível transcendente, porém a relação entre os dois é ambígua, dependendo de uma estrutura contratual. Destinador desenvolve o papel de manipulador, enquanto destinatário de sujeito com competência para desenvolver uma ação (GREIMAS \& COURTÉS, 2013, p. 333).

E ainda teremos o nível discursivo, que Greimas chamou de Percurso temático, que seria a manifestação isotópica, de uma possível leitura sem ambiguidades, a descoberta do tema (GREIMAS \& COURTÉS, 2013, p.496).

Fiorin (2014, p. 20), retira do dicionário de Greimas e Courtés a definição para o Processo Gerativo de Sentido: "uma sucessão de patamares, cada um dos quais suscetiveis de receber uma descrição adequada, que mostra como se produz e se interpreta o sentido, num processo que vai do mais simples ao mais complexo".

O autor procura ilustrar o esquema do percurso gerativo de sentido (FIORIN, 2014, p. 20), ao reproduzir o esquema greimasiano onde o nível profundo e $\circ$ nível de superfície enquadram-se nas estruturas semionarrativas, sendo possível a exploração de um componente sintático e semântico em cada um deles. Nas estruturas discursivas encontramos a sintaxe discursiva, o que Greimas chamou de Discursivização (actorialização, temporalização, espacialização); e a semântica discursiva, onde temos a Tematização e a Figurativização.

É no nível narrativo que encontramos o modelo canônico da narrativa. Teremos um destinador e um destinatário; a Manipulação: querer e/ou dever (pedido, ordem, sedução...); Competência: poder e/ou saber; Performance: 
passagem de um estado para outro; Sanção: julgamento, recompensa ou punição na constatação da realização ou não da performance.

O problema da ampliação do sentido com base em análises parciais das redações que fizeram parte desta coleta de dados poderia ser resolvido com a proposta de intervenção por meio de sequências didáticas que apresentassem a teoria semiótica de Greimas. Ocorre que estávamos lidando com a interpretação de um texto sincrético. Logo, a Teoria Semiótica da Figuratividade teria que ser acionada por se tratar de uma das teorias mais competentes da atualidade ao propor novas possibilidades em estratégias de leitura, compreensão e entendimento de texto sincrético, a imagem acoplada à escrita, caso específico das HQs.

A Teoria Semiótica da Figuratividade Visual criada pela professora e pesquisadora Nícia Ribas D' Ávila em meados dos anos 80 - 90 foi inspirada no Percurso Gerativo do Sentido, de Greimas. Esta teoria foi elaborada para analisar as imagens, obras de artes, esculturas, música, ou seja, todos os elementos que permeiam a arte que é vista como linguagem ou texto e permite apreender, desconstruir e gerar um enfoque do sentido inserido nos textos visuais, visto que toda a imagem possui um engendramento de traços e formas portadores de sentido, onde estas figuras falam de modo coerente.

Estes elementos figurais apresentam-se investidos de uma espécie organizada de semas englobantes, tais como: tracema, colorema, cromema, textuarema, densirema, saturema, largurema, alturema, extensurema, profundema, etc. Esses termos foram criados por D'Ávila e são neologismos por derivação para torná-los mais accessíveis e aplicáveis segundo a complexidade da teoria em questão. Os semas englobados apresentam-se nas categorias semânticas tais como: claro/escuro, longo/curto, alto/baixo, grosso/fino, entre outros.

São as marcas tipográficas, estes tracemas, os pontos, os pontuemas (D'Á VILA, 2007 e 2015), as linhas, as linhas curvas, que vão funcionar como estimuladores oriundos do texto e do repertório, do conhecimento adquirido 
pelos alunos e que possibilitam a compreensão e a construção da coerência.

Os traços que constituem as HQs são abundantes e precisavam de um estudo, porque representam o momento anterior ao desenho propriamente dito, o que a semioticista vai chamar de figural, aquele traço inicial que vem antes do figurativo (D'Á VILA, 2007, p. 32). Segundo D'Ávila $(2015$, p. 108) tracemas são os semas do traço/linha, i.e., os traços ou linhas que unem os pontos (pontuemas). Afirma D'Ávila que "A linha, enquanto iteratividade dos pontos/traços é uma unidade de base mínima primitiva e significativa na imagem. Ela é, enquanto signo, a menor distância entre dois pontos/traços" (2015, p. 108). Para a semioticista é preciso considerar sua "superfície, posicionamento, direcionalidade e finitude" $(2015$, p. 108) que são definidas pelos seus tracemas.

Ao ampliar esta metodologia, D'Ávila realiza um anseio de Greimas: afastar a linguagem não verbal da verbal, diante da análise semiótica dos conteúdos, mostrando assim, a autonomia e arcabouço semióticos dos conteúdos de caráter não verbal.

A estruturação do percurso para a análise do não verbal assemelhase ao Percurso Gerativo do Sentido proposto por Greimas. Os elementos figurais como os tracemas, as linhas curvas, os pontos são perceptíveis por parte dos alunos que inferem a partir deles, conotações eufóricas ou disfóricas, como se pôde constatar numa amostra de 56 redações que trazem o antes e o depois das atividades didáticas com a teoria semiótica.

A escolha do gênero textual "tirinha" para interpretação do primeiro grupo deveu-se ao fato de que, por estar no livro didático, é pressuposto que seja considerado como adequado para a faixa etária e escolaridade dos alunos pesquisados, mas poderia ser qualquer outro gênero que atendesse aos propósitos da atividade.

A escolha da HQ de Maurício de Sousa para interpretação do segundo grupo foi um trabalho mais difícil, pois deveria ser um pouco mais longa que uma tirinha, mas não tão extensa e deveria conter elementos de 
narratividade que pudessem ser percebidos pelos alunos. Outro fator importante é que os dois gêneros textuais trazem a linguagem verbal e nãoverbal, ou seja, trata-se de um texto sincrético (verbo-visual)5, cuja interpretação mostra a contribuição de D’Ávila com este vasto campo de pesquisa que a semiótica francesa ora desenvolveb.

O texto verbal como sabemos é aquele texto que é representado por elementos textuais (palavras) e seguem uma estrutura de acordo com o gênero específico. O texto não-verbal é aquele representado por imagens, sem o suporte da palavra. Já o texto sincrético é a junção dos dois. De acordo com Greimas \& Courtés (1979),

\begin{abstract}
"o sincretismo como procedimento (ou seu resultado) que consiste em estabelecer, por superposição, uma relação entre dois (ou vários) termos ou categorias heterogêneas, cobrindo-os com o auxílio de uma grandeza semiótica (ou linguística) que os reúne." (GREIMAS \& COURTÉS, 1979, P. 426)
\end{abstract}

No caso das tirinhas e HQs, além do verbal, são incluídos o gestual, as expressões das personagens, o tamanho da letra, as onomatopeias e a disposição das imagens em relação às palavras, traços e pontos. É neste sentido "mais amplo" que "foram consideradas" as tirinhas e HQs, como dizem os semioticistas aqui referenciados que chamam de sincréticas "as semióticas que - como a ópera ou o cinema - acionam várias linguagens de manifestação" (GREIMAS \& COURTÉS, 1979, p. 426). As tirinhas e HQs, portanto incluem-se igualmente nessas linguagens.

\footnotetext{
5 Conforme define D'Ávila em seu livro (2007). Confira Referência Bibliográfica.

6 Nossas pesquisas sobre semiótica aplicada ao texto não verbal não se resumiram ao trabalho de D'Ávila. Há outros pesquisadores que buscam desvendar as possíveis "Caixas Pretas" (Pesquisas de Santos em andamento) deixadas por Greimas em sua semiótica, como é o caso de Ana Claudia de Oliveira, Lúcia Teixeira e Claude Zilberberg (que revisita o próprio conceito de sincretismo) dentre outros que têm sua importância e dão a sua contribuição, mas nenhum deles como as duas obras de D'Ávila $(2007,2015)$ que mostram que a semioticista teria preenchido uma destas "lacunas", posto que é a única a apresentar um arcabouço teórico que dá conta do figural que antecede o figurativo. Termos como "tracemas", "pontuemas", por exemplo, abundantes em HQs, são neologismos que fazem parte deste arcabouço criado por D'Ávila.
} 
Comprovada a preferência dos alunos pesquisados no ensino fundamental pelas HQs e tirinhas ao longo de muitos anos em sala de aula percebemos que mesmo com a crise da leitura, esse gênero nunca escapa a sua escolha. Cada vez mais, são criados heróis e anti-heróis nas HQs, que são admirados por eles. As HQs estão em todos os lugares: jornais, gibis, até mesmo nos livros didáticos, com o intuito de chamar a atenção desse jovem público leitor. Elas também estão nas análises semióticas.

Ivan Lopes e uma série de articulistas em "Semiótica, objetos e práticas" (2013), falam da semiótica aplicada à canção, ao cinema, a dança, ao discurso político, ao futebol, a mitologia, a publicidade, a literatura e as HQs. Esse trabalho, portanto, do ponto de vista da análise das HQs não é inédito, o que apresenta de novo é a experiência do trabalho com as tirinhas e HQs, em termos locais, na escola pública de Três Lagoas, expostas para a análise dos alunos e a apresentação da teoria daviliana como instrumento de sua análise.

Este foi o corpus apresentado aos alunos que produziram 56 redações, 28 antes da S/D e 28 depois, das quais apresentamos as 10 primeiras produções a fim de verificarmos se houve ou não ampliação da percepção do sentido no interior do enunciado de caráter sincrético: 


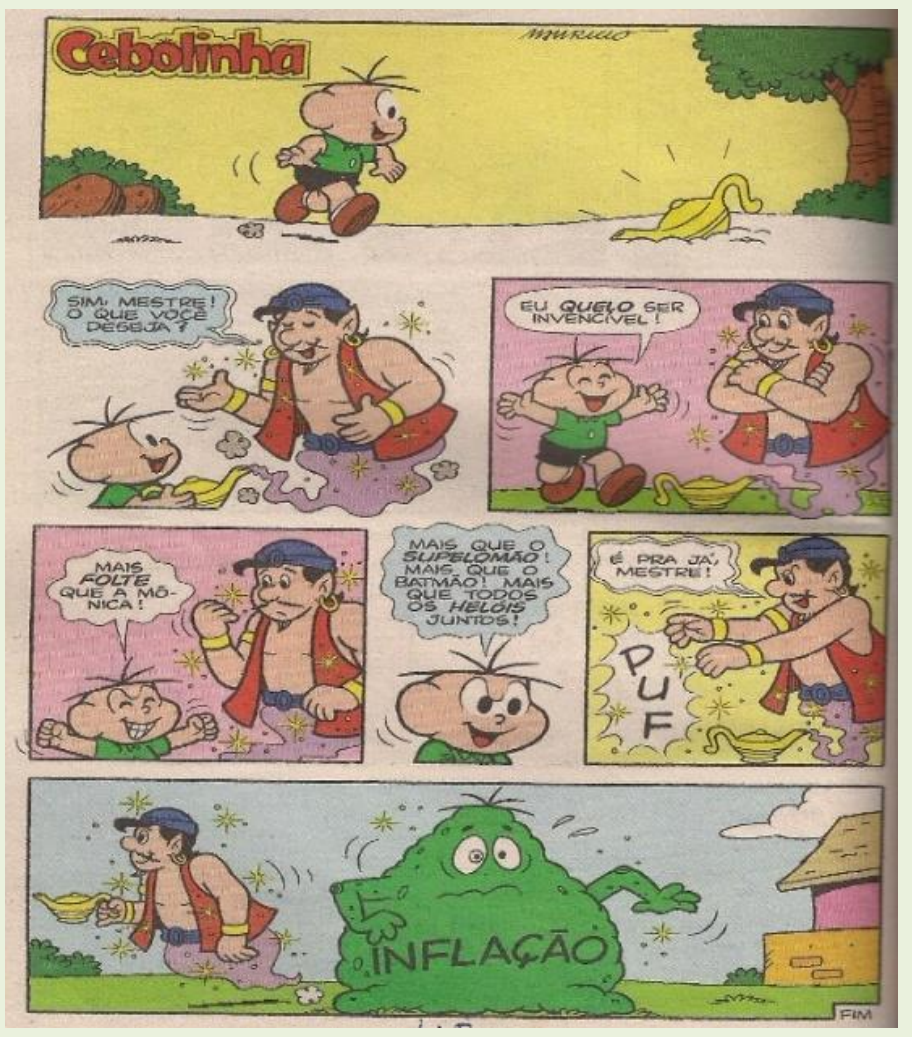

\section{Análise comparativa da interpretação inicial e final após a SD}

Aluno A, redação I

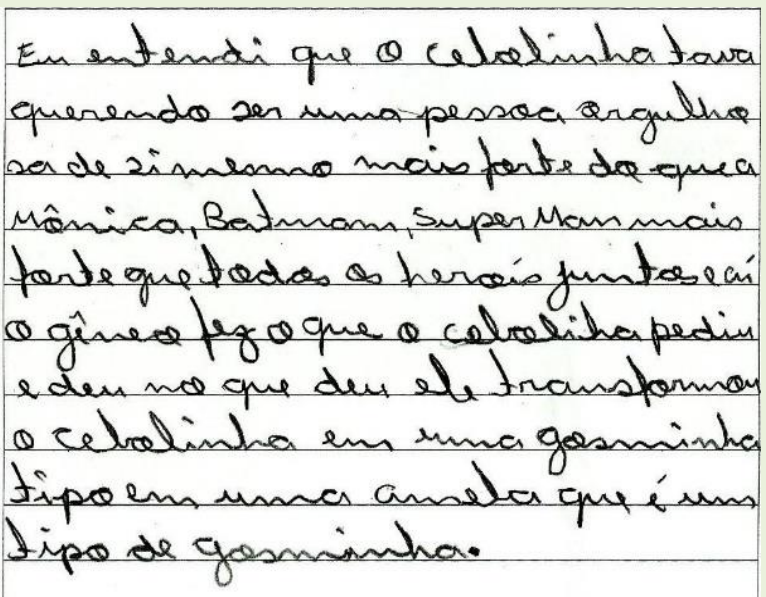

Pode-se perceber que em seu primeiro texto, o aluno A, narra a história que leu, fazendo uma espécie de resumo da HQ. Ele conta o óbvio, o que conseguiu enxergar da história em quadrinhos, apresetando marcas de uma linguagem oral e cotidiana em "tava" ao invés de "estava", usando "e aí" para representar a continuidade de seu discurso ao invés de usar uma conjunção, ou a pontuação adequada para esse momento de escrita.

Língua falada e língua escrita são dois sistemas com estreita relação utilizados por eles. São dois sistemas de signos diferentes entre si, mas que 
acabam se misturando intimamente. A fala é nata, a língua escrita, inata. Por ser a escrita representação da fala, alguns alunos desta faixa etária, ou ainda aqueles que não se apropriaram de todas as particularidades da língua escrita, escreveram exat amente como falam.

A primeira escrita revela um narrador que mostra a compreensão do texto pautada no /querer/ do actante-sujeito principal, Cebolinha, papel temático, como sujeito da auto-sanção cognitiva positiva, porque queria ser "mais forte do que a Mônica, Batman, Superman, mais forte que todos os heróis juntos" e a transformação de Cebolinha numa "gosminha" pelo gênio. Já seu segundo texto apresenta uma organização em parágrafos, mesmo que não muito bem marcados.

Redação II

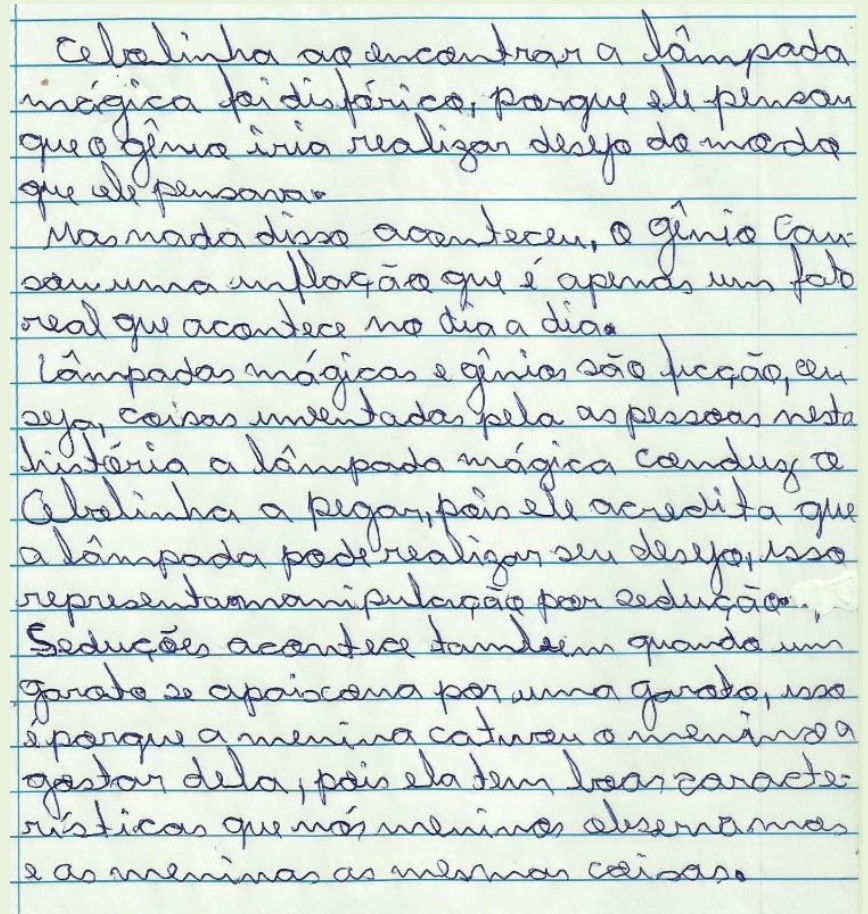

No primeiro parágrafo percebe a frustração, no nível da abstração, das modalidades tímicas "euforia" versus "disforia", utilizando o termo negativo no eixo dos contrarios, revelador da quebra da expectativa do actante sujeito que se pode chamar de S1, por ocupar o papel principal em seu fazer no interior do texto em seu contracenar com S2 (sujeito 2), o gênio, objeto modal da realização de seu desejo. 
Ele inicia o segundo parágrafo dando continuidade ao primeiro com uma conjunção adversativa "mas", estabelecendo uma oposição, para chamar a atenção do leitor (BECHARA, 2014, p. 130) e para dizer que o personagem não conseguiu o que imaginava, identificando a inflação como algo real, fazendo parte de uma história fictícia.

Mesmo não utilizando bem o verbo "causar", não interfere no entendimento do que o aluno quis dizer, sendo somente um deslize por não encontrar, naquele momento específico de escrita, o verbo transformar ou tornar, verbos que manifestariam melhor o significado do que quis dizer.

Em seguida verifica-se que o aluno conseguiu identificar a categoria semântica da ficção versus realidade imprimida na $H Q$ do primeiro nível de leitura do texto, o nível fundamental, mergulhando para o nível narrativo ao identificar que o ator social "Cebolinha", foi manipulado por sedução pela imagem da lâmpada, que se transforma num gênio que, por sua vez, faz parte de um mundo ficcional, explicando também que a lâmpada mágica além de fazer parte da ficção foi o objeto que causou em Cebolinha a manipulação, pois era o meio pelo qual ele poderia conseguir algo que queria.

Neste caso temos uma inversão de papéis, porque o que é objeto modal para o gênio em seu Programa Narrativo da transformação, doravante PN, torna-se sujeito manipulador de Cebolinha e este é um caso em que objeto passa a ser sujeito e sujeito passa a ser objeto.

Segundo Santos (2015, p. 93), os objetos modais "São utilizados pelo destinador para modalizar o destinatário, isto é, dotá-lo do /querer, poder, saber, dever/, tornando-o competente no desempenho de seus programas narrativos".

Tem-se na HQ uma inversão de papéis actanciais. Cebolinha, papel temático do sujeito que age no interior do texto, por isso se chama na semiótica actante sujeito, de destinador passa a destinatário manipulado pela crença (/crer/) de que ao encontrar a lâmpada/pode/ ter o seu desejo realizado, ao que o narrador textual vai dizer "isso representa a 
manipulação por sedução", mostrando que captou que esta manipulação se dá porque faz o sujeito parar e olhar e é exatamente o que ocorre se o foco de análise for a linguagem não verbal do primeiro quadro, ao se observar a fisionomia do actante sujeito em seu encontro com a lâmpada.

Santos (2015), nas pegadas de Greimas e Courtés, explica que é na relação do sujeito com o objeto que se marca a existência e a distinção de ambos. Desta forma, pode-se distinguir o actante-sujeito do /fazer/, exercendo seu papel actancial, cujo papel temático está investido no conhecido personagem "Cebolinha", parte do repertório cultural do aluno, do objeto lâmpada que passa a sujeito ao /fazer/ Cebolinha (o sujeito em ação) /crer/ que aquilo pode torná-lo um sujeito realizado, fazendo-o sair de uma situação de junção, como sujeito disjuntivo, logo, virtualizado, para a situação de sujeito que pode realizar seu desejo.

O aluno, em sua segunda escrita, após a sequência didática, ousa ainda dar um exemplo da manipulação por sedução, quando diz que meninos ou meninas apresentam "algumas caracterísitcas" que seduzem um ao outro, "cativam" e levam ao apaixonamento.

Aluno B, Redação III

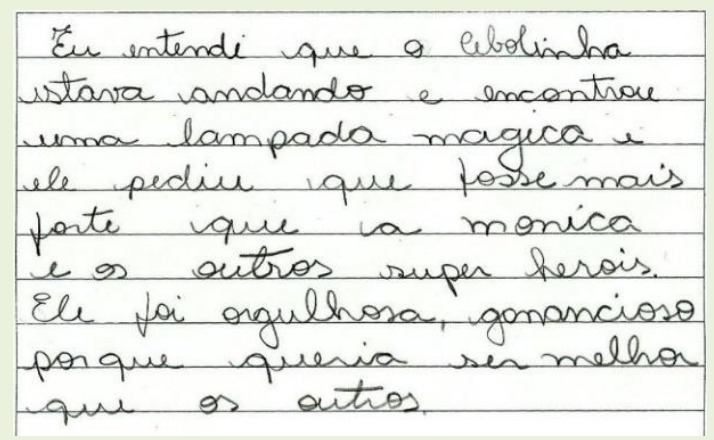

No primeiro texto do aluno $B$, pode-se perceber que igualmente ao aluno "A", seu texto foi escrito demonstrando somente aquilo que está na superfície do texto, detendo-se somente a narrar as ações desenvolvidas na HQ. O que não acontece em seu segundo texto, já que apresenta mais conceitos referentes a aspectos mais abstratos no texto, que só são 
perceptíveis a quem os conhece e reconhece por meio de uma leitura mais cuidadosa.

No primeiro parágrafo ele se limita a um resumo da $\mathrm{HQ}$ e, no segundo, aplica uma sanção negativa cognitiva ao atribuir ao actante sujeito S1, a caracterização do sujeito "orgulhoso", "ganancioso", sujeito do /querer-ser/ "melhor que os outros".

É o que Barret ( 1968) cit ado por Santos em seu artigo "Na interface das estratégias de leitura instrumental e a leitura crítica: Reflexões e Sugestões" vai chamar de apreciação, "momento em que o leitor faz um julgamento final, emite sua opinião" (SANTOS, 2013, p. 70-71).

Já em sua segunda redação se percebe um texto mais estruturado e dividido em parágrafos.

Aluno B, Redação IV

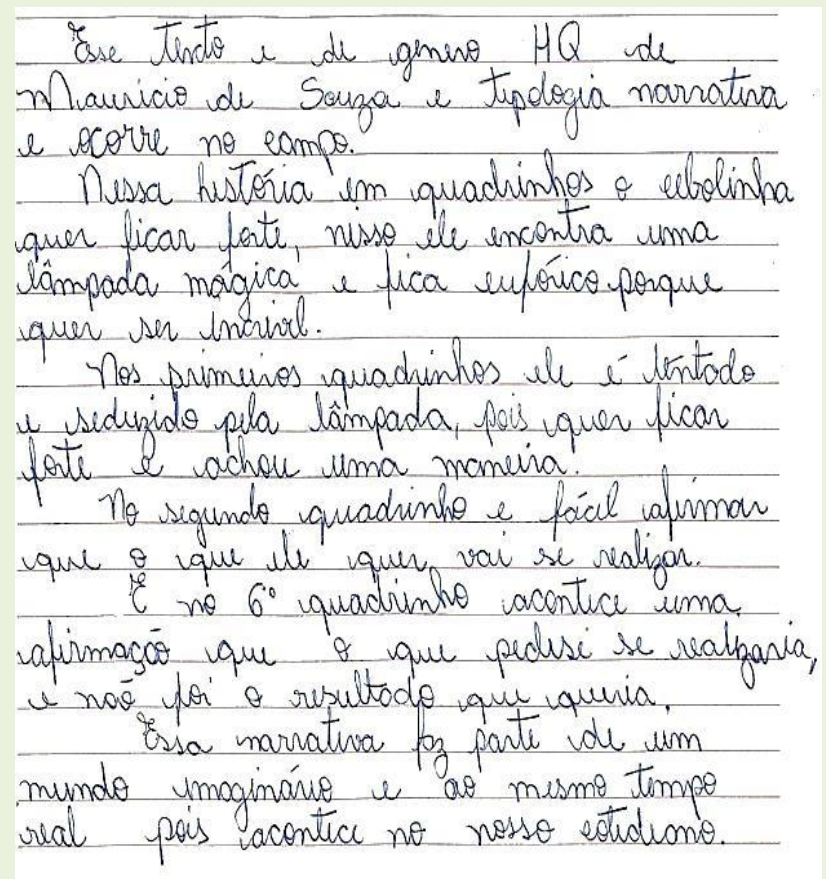

No primeiro parágrafo, apresenta elementos da superfície do texto, tais como gênero e tipologia textual, autor e local onde se passa a história. Isto mostra que se conseguiu, como sugere Ingedore Grunfeld Villaça Koch (2014, p. 174), "levar o aluno a uma reflexão sobre como se produzem sentidos na interação por meio da língua, ou seja, por intermédio de textos", 
por meio das práticas metacognitivas, antes mesmo das atividades inspiradas em sequência didática com o uso da semiótica.

Aciona-se, aqui, o seu conhecimento prévio, remetendo-o ao autor da $H Q$, Maurício de Sousa, e à identificação do gênero textual HQ. Além disso, verifica-se que, embora não fale do nível discursivo, descreve que o evento da cena ocorre no espaço "campo", o que neste nível se explora como espacialidade, local de ação do ator dentro de um determinado tempo, conforme o nível discursivo da semiótica francesa.

No segundo parágrafo, segue narrando o que acontece na $\mathrm{HQ}$, mas introduz o conceito de euforia adequadamente ao dizer que Cebolinha fica eufórico por saber que a lâmpada mágica resolveria seus problemas o que se pode pressupor que descobriu pela relação do sujeito com o objeto, ao observar o gestual, as marcas da alegria no rosto daquele sujeito que age no primeiro quadrinho onde a linguagem é apenas não verbal.

Essa visão é ampliada pelo sincretismo de linguagens do segundo quadro, a sequência II do enunciado em questão, quando o narrador da $\mathrm{HQ}$ concede voz ao gênio, produto da garrafa, demonstrando que houve a narratividade dentro de seu texto sincrético, uma vez que esta se caracteriza pela transformação do sujeito no interior do texto.

O gênio se coloca à disposição como sujeito operador de seu desejo de se tornar "invencível" e isso é captado pelo aluno ao afirmar que Cebolinha "quer se tornar invencível", ou seja, foi manipulado pelo gênio.

No terceiro parágrafo reconhece os conceitos de manipulação por tentação e sedução adequadamente, o primeiro porque se caracteriza pela oferta de algo material ao destinatário da mensagem e o segundo conceito por conta de ser uma imagem de algo que faz o sujeito parar diante de si e o olhar.

Na imagem da sequência I da $H Q$, a lâmpada apresenta-se diante de seu olhar e o faz inferir que ali está a chave da realização do seu desejo. É como se a lâmpada oferecesse a si mesma, ao sujeito como objeto modal, para sua competência e, ao mesmo tempo, como sujeito operador da 
missão da transformação de seu estado de disjunto a conjunto com a invencibilidade.

No quarto e quinto parágrafo descreve o que se afirma e o que se nega durante a $H Q$, explicando que no primeiro quadrinho o at or Cebolinha tem a afirmação de que poderá, enquanto actante sujeito, realizar seu desejo.

Porém, no sexto e último quadrinhos o sujeito não consegue entrar em conjunção com o objeto de desejo: ser mais forte, conforme se pode ver no último parágrafo, em que sua expectativa é frustrada pela surpresa, porque ao invés de ser transformado, sair de um estado de disjunção com a invencibilidade para a conjunção com o ser "mais forte", "invencível", temse a imagem de um animal que não corresponde com os termos comparativos utilizados como analogia pelo sujeito, como as figuras emblemáticas do "supelomão", "batmão" e "todos os helóis juntos".

Ele queria ser uma espécie de "supercebolão", cujo desejo, no plano da imanência textual, é ser ainda superior que todos os heróis juntos, fazendo surgir a categoria semântica do superior versus inferior.

Ao afirmar, no entanto, que a narrativa faz parte de "um mundo imaginário e ao mesmo tempo real" dá mostras de que percebeu a ironia da narrativa sincrética de Maurício de Sousa que se utiliza de sua arte como objeto modal para gerar reflexões sobre o cotidiano, ao estabelecer a figura da "inflação" que remete ao mundo real, não mais ficcional. 
Aluno C, Redação V.

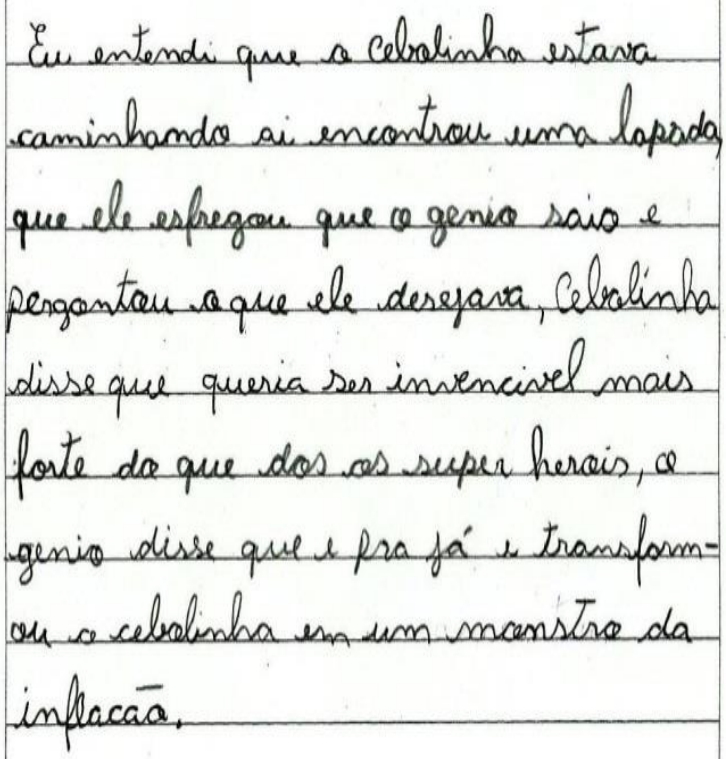

O primeiro texto do aluno $C$ foi estruturado em um parágrafo, com alguns deslizes por não fazer uso da norma culta e por falta de pontuação, acentuação de palavras em "lapada" na segunda linha, "genio" e "saio" na terceira, "invencivel" na quarta linha, "herois" na quinta e novamente "genio" na sexta linha, além de utilizar a palavra "ai" na segunda linha, onde poderia ter usado vírgula.

Do ponto de vista do sentido, sua leitura do texto é superficial, destacando o que é lido e visto na $H Q$, narrando somente com elementos explícitos.

Ele narra o encontro entre Cebolinha, papel temático, e uma lâmpada de onde ele, Cebolinha, tirou um gênio que o transformou num monstro chamado inflação.

Sua primeira redação mostra um percurso narrativo desde um sujeito destinador manipulador que faz com que um sujeito operador realize uma transformação, a de Cebolinha num monstro da inflação, mostrando a narratividade de seu texto. No entanto, não há uma visão crítica em que possa inferir a relação entre a inflação da HQ e a inflação na vida real. 
Em seu segundo texto, pode-se perceber que o aluno $C$ preocupou-se um pouco mais com a estrutura de seu texto, organizando-o em parágrafos. Alguns deslizes com a ortografia continuaram, mas percebe-se evolução em seu texto no que se refere ao sentido. Observe:

Aluno C, Redação VI.

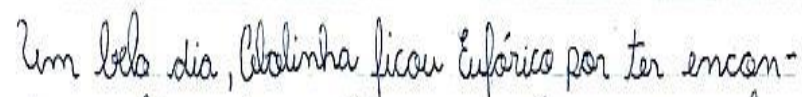
trado um lâmpada por ter uma relacäs de ganho. Par que bimalmente seu deseo reria reatizado.

ho mesmo instante um géneio aparaceu fai positivo por poder realizar a desefo, no momento - de pedir o deseja, de ser invencível, incrível que Losse mais forte aue mónica e todas as super - herais juntas.

ha sitimo auadrinho scantece o mamenta en que a pedido foi realizado e nāo foi que ele quiz. Cesse texto e narrativo es de autor mauricio de Souza.

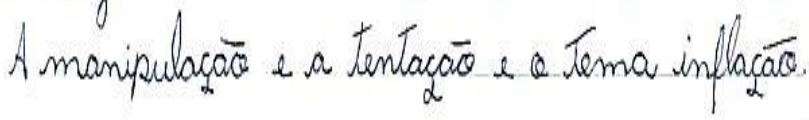

Seu texto agora é composto por cinco parágrafos. No primeiro, utilizase do conceito de euforia, associando-o a uma relação de ganho, em seu encontro com o objeto modal lâmpada, utilizada para torná-lo sujeito realizado. Esse aluno narrador agora faz seu leitor inferir que a perda seria tida como disfórica, posto que ninguém gosta de perder.

No segundo parágrafo diz que quando o gênio aparece acontece algo positivo para Cebolinha, identificando o conceito de euforia, embora não o empregue como tal. Ele não discorre sobre a manipulação e qualifica o gênio de maneira antecipada, limitando-se a informar que Cebolinha pediu ao monstro que realizasse o seu desejo. 
No terceiro parágrafo, numa contradição, diz que o "pedido foi realizado" e reconhece que Cebolinha foi frustrado em seu pedido, porque não teve a força dos super-heróis desejados, mas se transformou no monstro da inflação, em suas palavras, "não foi que ele quis".

Embora não se utilize do termo disforia, todavia, esta aparece neste parágrafo, ao perceber que não teve seu desejo realizado, o que mostra um sujeito que estava em disjunção com a força concentrada dos super-heróis e assim permanece, embora adquira a força da inflação. Logo, a relação de perda e ganho só poderá ser admitida em função de sua transformação de não /poder/ a /poder/ ser tão forte quanto os super-heróis.

No quarto parágrafo explica que se trata de um texto narrativo, identificando sua tipologia e seu autor e finaliza sua análise, no quinto parágrafo, afirmando que há uma manipulação por tentação, o que, na verdade, não ocorre, porque Cebolinha não oferece nada no plano pragmático, quando se dá algo material para que o outro faça o que se pede.

Não há, por esta razão, a manipulação por tentação, mas uma espécie de manipulação por sedução, se observarmos os traços de alegria (euforia) no rosto de Cebolinha, ao olhar para a lâmpada que, pelo desenho, observando-se os tracemas que remetem para o corpo da lâmpada e para o seu bico, está em estado de ebulição, levando à interpretação de que é um objeto que ejetará, a qualquer momento, em posição paradigmática, algo de seu interior.

É essa euforia flagrada no rosto de Cebolinha, por meio do tracema no seu rosto horizontal e curvo (sorriso) que nos induz a pensar que ele é sujeito do /saber/ que da lâmpada sairá um gênio, de que alguém poderá /fazer/ seu desejo se realizar. Assim, a sua reação diante do objeto para o qual olha faz com que se acredite que o objeto, naquele momento, vira sujeito e o manipula por sedução, caracterizada pelo /fazer/ o sujeito /parar/ e olhar. Não se vê a parada de Cebolinha, mas um andar contínuo em direção ao 
objeto, cuja fisionomia leva a /crer/ que dali sairá algo bom, que está gostando do que vê e que foi seduzido.

Entretanto, ainda que discreta, pode ser percebida uma evolução em termos de organização dos parágrafos e do uso de vocabulário que remetem ao ensinado na sequência didática e à aplicabilidade de alguns dos conceitos semióticos, demonstrando o aluno analista que reconheceu aspectos mais peculiares à interpretação textual, percorrendo o seu tema principal.

Aluno D, Redação VII

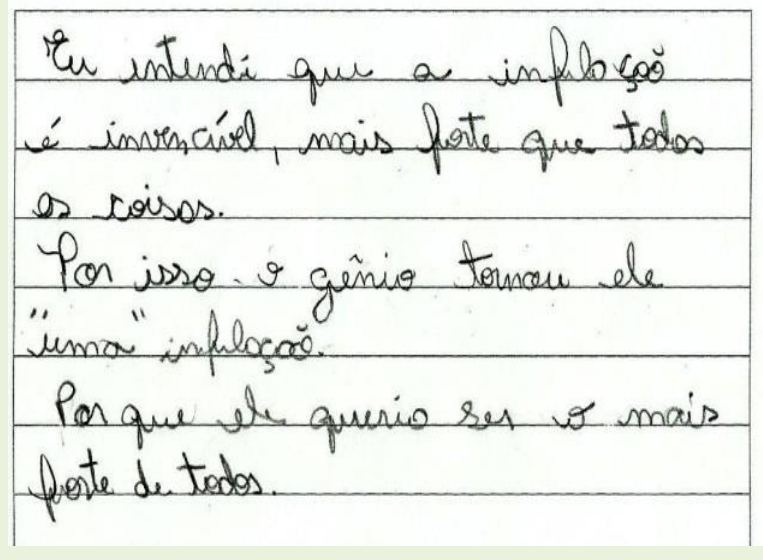

Das redações até aqui analisadas, esta do aluno $D$ é aquela que mostra não um resumo, mas, de fato, uma interpretação, dividida em três parágrafos com orações curtas.

Ele consegue expressar, já no primeiro parágrafo, que a inflação é mais forte que todas as coisas por meio da palavra "invencível" e faz uso da conjunção conclusiva "por isso", coordenando a segunda oração à primeira. Já no terceiro parágrafo faz uso da conjunção explicativa "por que" na intenção de explicar o que escreve nos parágrafos anteriores.

No terceiro parágrafo, ao usar a conjunção explicativa "por que", denotando uma explicação, não se consegue perceber se a oração está coordenada ao primeiro ou ao segundo parágrafo. Pode-se perceber que a intenção do aluno foi arrematar sua ideia desenvolvida na sua tese de que 
ele queria ser "mais forte que todas as coisas" e que, "por isso", o gênio o transformou "numa inflação".

Esse aluno consegue ir um pouco além de um nível superficial de leitura, pois consegue relacionar o explícito com o implícito no texto, ao fazer uma interpretação ordenada, identificando logo no primeiro parágrafo o tema principal, concluindo no segundo parágrafo o motivo pelo qual o gênio transformou Cebolinha na inflação e explicando, no último parágrafo, o motivo do /fazer/ do gênio.

A sequência de parágrafos, no entanto, não é linear, posto que a explicação poderia vir antes da conclusão e não no final, mas isso não tira o mérito de sua captação do sentido do texto. Ele delega o /saber-fazer/ ao gênio, colocando-o numa relação semântica de superior à Cebolinha que não capta o espírito da transformação, enxergando apenas os super-heróis como superpoderosos e invencíveis, ficando no plano da ficção quando é a realidade que interessa.

Já em sua segunda redação, identifica o gênero textual e o seu autor, fala sobre a história, onde se passa e qual a ação do personagem, como se vê no primeiro parágrafo. Percebe-se que acionou o seu conhecimento prévio, o que Umberto Eco (1984) vai chamar de "não-ditos", tipos de lacunas que são preenchidas pelo leitor em sua colaboração com a interpretação.

Vendo a HQ como um "tecido" repleto destas "lacunas", é possível dizer que $O$ narrador textual foi competente em relação ao seu preenchimento. 
Aluno D, Redação VIII

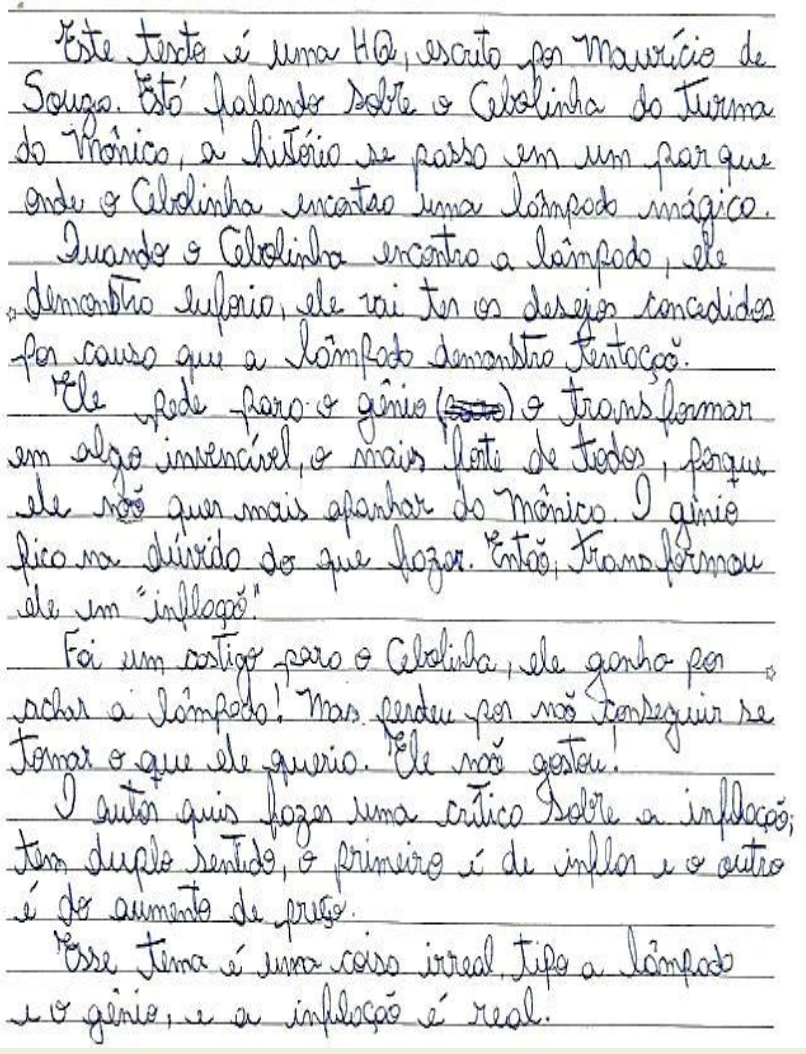

Entende-se por conhecimento prévio na esteira de Charolles e Ehrlich (1986) três tipos de conhecimento: de mundo, linguístico e textual, o que Santos (2013) vai chamar de "repertório cultural", isto é, as informações e experiências armazenadas na memória das pessoas ao longo de seu enredo de vida. Para o articulista, com a combinação das estratégias de leitura instrumental e a semiótica, é possível ir além do efeito de sentido:

As estratégias de leitura instrumentais funcionam quando se busca valorizar o repertório cultural dos alunos, dando-lhes as dicas explicitas no texto, como a observância do título, figuras, cognatos, marcadores discursivos, inferência, etc., rumo à compreensão do enunciado, mas é preciso que o aluno também adquira estratégias para uma leitura que vá além dos efeitos de sentido, aquela apreensão imediata que se tem do que se lê (2013, p.62)

Ao afirmar que "quando o Cebolinha encontra a lâmpada, ele demonstra euforia", embora não descreva os tracemas que o levam a /crer/ nesta euforia, estampados no rosto do actante-sujeito principal da $H Q$, ele 
consegue visualizá-los, explicando que ele vai ter seu desejo realizado, fazendo uma previsão inadequada, tal qual aquela que fez o próprio Cebolinha, porque o gênio realiza uma performance e pode ser considerado como sujeito competente, mas não a realiza Cebolinha com a sua performance, porque sua expectativa, tal qual a do narrador aluno, não se concretiza.

Só se fala de uma manipulação por tentação se for possível enxergar alguém a oferecer a lâmpada ao Cebolinha. Se pensarmos, todavia, que a lâmpada é um objeto que se transforma em sujeito e se oferece a Cebolinha, aí sim, podemos falar de uma manipulação por tentação.

Não podemos falar tampouco de um desejo realizado, porque os traços curvilíneos ${ }^{7}$ da boca do monstro da inflação e a circularidade dos seus olhos, não lidos pelo aluno analista, revelam um estado de alma disfórico, desde os semas que o descrevem à própria qualidade de "monstro" que assume, tão negativo quanto à inflação, no plano real.

No terceiro parágrafo o aluno ativa o conhecimento prévio que tem em relação às HQs da turma da Mônica, "porque ele (Cebolinha, infere) não quer mais apanhar da Mônica". Ele dá mostras de que considerou o não verbal também em sua interpretação, pois diz que o gênio fica em dúvida, mas isso não está escrito na $H Q$, o aluno percebe pela expressão facial do gênio, pelos traços que perfazem sua fisionomia. Esses traços da dúvida rementem, por outro lado, ao sujeito cognitivo, o sujeito do pensar em "arrumar" uma solução para o problema de seu destinador e pode, portanto, sob este olhar, soar como eufórico ao invés de disfórico.

Há, na verdade, toda uma narratividade no gestual do gênio, sujeito operador da transformação, desde o momento em que se oferece à disposição, no segundo quadro da HQ, com os braços parcialmente abertos e as mãos que oferecem o /fazer/ transformador, ao último parágrafo.

\footnotetext{
${ }^{7}$ Ler D'Ávila "Semiótica Sincrética..." (2007) conforme Referências Bibliográficas.
} 
De sua mão direita saem pontuemas ${ }^{8}$ e estrelas e da parte inferior, tracemas inclinados que levam à temática do fato mágico, passando pelo segundo quadro do seguimento II, quando cruza os braços que mostram em seu entorno nos ombros e braços o deslocamento espacial das estrelinhas e pontuemas, agora girando, indicando a dinamicidade da preparação para a ação, como se vê no quadro primeiro da sequência três, modificando seu estado, ao se mostrar como sujeito pensante, da dúvida captada pelo aluno analista e culminando, com o seu fazer transformador ao executar sua performance.

O resultado esperado pelo destinador, no entanto, não é o desejado, o que faz, finalmente, que se retire, já na última sequência, com a lâmpada nas mãos, enquanto Cebolinha, agora transformado no monstro da inflação, mostra a decepção como sanção cognitiva negativa à performance do gênio.

No quarto parágrafo o aluno capta essa sanção negativa ao se referir ao "castigo" recebido por Cebolinha, mostrando a relação de ganho e perda do actante-sujeito em seu PN da busca da transformação, que "não gostou" do que aconteceu, isto é, não conseguiu terminar sua performance naquilo que "ele queria". Esse sujeito da frustração é captado pelo aluno analista pela leitura dos traços particularizantes que formam um todo de sentido na fisionomia do monstro da inflação.

No quinto parágrafo o aluno fala do /querer/ do produtor da $H Q$, como o sujeito do /querer-fazer-saber/ sobre os aspectos disfóricos, negativos da inflação, chegando a identificar os dois sentidos do lexema: inflar e aumentar o preço.

O gênio, deste ponto de vista, pode ser considerado como sujeito realizado, o que não ocorre com Cebolinha, apesar de ter o seu pedido atendido. Oras, se ele teve seu pedido atendido, porque, então, não é

\footnotetext{
8 Pontuemas, tracemas, etc. são neologismos criados por D’Ávila e que fazem parte do arcabouço da teoria daviliana também conhecida como teoria da figuratividade visual. Leia-se seus livros de 2007 e 2015 que constam da referência bibliográfica que mostram com detalhes sua contribuição para a análise do texto sincrético.
} 
sujeito realizado? Justamente por conta de seu fazer interpretativo. Ele não gostou de ser transformado num monstro, mas queria ser um super-herói.

Ele não gostou porque não entendeu "o espírito da coisa", enquanto o produtor da $\mathrm{HQ}$ cumpriu o seu papel, ao trazer à tona o humor próprio da $H Q$.

No sexto e último parágrafo, o aluno identifica a oposição semântica "real versus irreal", mostrando que a crítica foi sustentada e construída por essa oposição.

AlunoE, Redação IX.

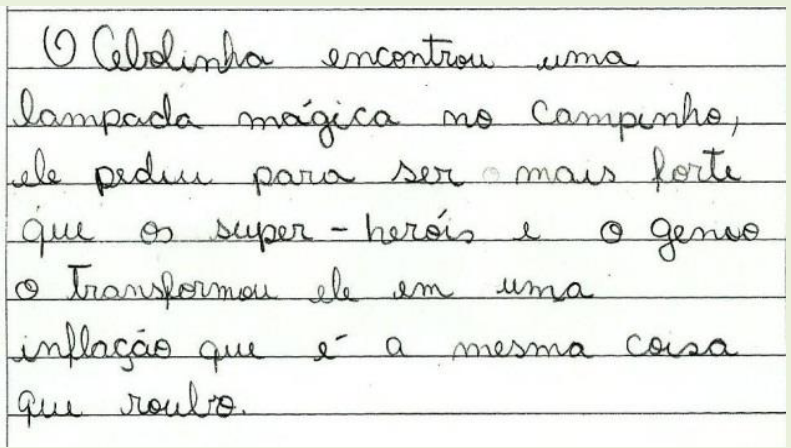

O aluno $E$, narra o que percebe na $H Q$ de forma superficial e rápida, limitando-se a um parágrafo para a escrita do seu texto. Apresenta $O$ personagem, o local onde acontece a história e o que aconteceu no final, mas atribui um sentido equivocado à palavra "inflação".

Em seu segundo texto fez uma exposição maior do que leu, explicando seu entendimento sobre o texto, dizendo no primeiro parágrafo que Cebolinha "sentiu uma mera atração" pela lâmpada, ou seja, foi manipulado por sedução, acreditando que na posse do objeto teria seu pedido realizado. 
Aluno E, Redação X.

\begin{tabular}{|c|}
\hline 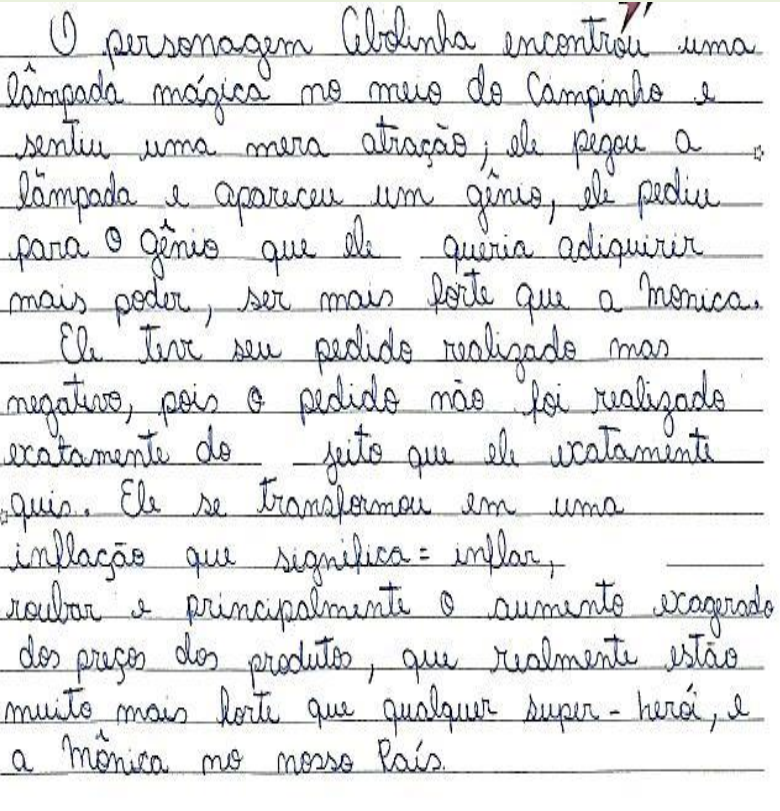 \\
\hline
\end{tabular}

Embora não utilize o termo "manipulação por sedução", no primeiro parágrafo, o aluno escreve agora que Cebolinha foi atraído, logo, seduzido pelo objeto lâmpada, demonstrando que conseguiu aplicar o sentido do conceito semiótico.

No segundo parágrafo diz que teve seu pedido atendido, mas que foi negativo por não acontecer exatamente aquilo que pediu ao gênio e ainda consegue atribuir três significados distintos a palavra "inflação" (inflar, roubar e o aumento exagerado dos preços dos produtos), percebendo qual a intenção do autor em colocar essa palavra na HQ.

\section{CONSIDERAÇÕES FINAIS}

As redações aqui analisadas são uma prova concreta de que é necessário que as pesquisas em torno da interpretação de textos, escrita e reescrita, sejam realizadas em sala de aula com a finalidade de melhorar 0 modo do aluno da Escola Pública ver (ler) o texto.

$O$ engendramento de tais pesquisas e teorias pôde mostrar que o trabalho com a interpretação de textos, num viés metacognitivo, com base 
nas técnicas de correção, na apreciação da primeira escrita e reescrita de texto, "textualização" e retextualização e semiótico, em que foram explorados os níveis possíveis de leitura do texto em sala de aula assumiram papel decisivo na ampliação da percepção do sentido no interior do texto por parte dos alunos pesquisados.

Dentre estas teorias experimentadas em interfaces, a teoria semiótica demonstrou-se como uma teoria capaz de fornecer um instrumental valioso na contribuição da leitura mais ampla em Língua Portuguesa, não mais superficial no ensino fundamental II, utilizando uma metodologia por meio do Percurso Gerativo de Sentido organizado sob inspiração na tradicional sequência didática. Além de ser relevante para a discussão de políticas públicas no município de Três Lagoas.

A teoria greimasiana, como é conhecida, tornou-se num eficiente objeto modal enquanto teoria utilizada para a análise das interpretações dos alunos, momento em que foi posta em prática na sala de aula, atendendo um desejo de seu precursor, que defendia sua popularização enquanto ciência da significação que trabalha com as linguagens verbal, não verbal e sincréticas.

Essa, aliás, é uma das principais virtudes desta semiótica, dar conta também do sentido do texto sincrético, elemento utilizado como corpus para a apreciação dos alunos. Neste sentido, há de se reconhecer os trabalhos desenvolvidos por D'Ávila que acrescentam, com a teoria da figuratividade visual, ao legado deixado por Greimas.

\section{REFERÊNCIAS}

AYTO, J. Arcade Dictionary of Word Origins. The histories of more than 8,000 English Language Words. Arcade Publishing, New York, 1990.

BAKER, L. BEAL, L. C. Metacognitive processes and reading comprehension. Chapter 17, https://cie581fall2009.wikispaces.com/file/view/Bakert+Metacognition.pdf 2009.

BARROS, D. L. P. de. Teoria Semiótica do Texto. 5 ed. São Paulo: Ática, 2011. 
BRASIL. Secretaria de Educação Fundamental. Parâmetros curriculares nacionais: terceiro e quarto ciclos do ensino fundamental: introdução aos parâmetros curriculares nacionais. Secretaria de Educação Fundamental. Brasilia: MEC/SEF, 1998.

BROWN, A. L. Knowing when, where, and how to remember: A problem of meta-cognition. In R. Glaser (Ed.), Advances in instructional psychology. Hillsdale, NJ: Erlbaum, 1978, Vol. 2, pp. 77-165.

CUNHA, A. G. da. Dicionário Etimológico Nova Fronteira da língua portuguesa. Rio de Janeiro, Nova Fronteira, $8^{a}$ Edição, 1997. Primeira edição data de 1982.

CHAROLLES, M., EHRLICH, Marie-F. Aspects of textual continuity; linguistic and psicological approaches. In: Texts and text processing. Poitiers, 22-25 sept. 1986.

D'ÁVILA, N. R. Semiótica verbal e sincrética, verbo-visual e verbo-musical teorias e aplicabilidade. Bauru, SP: Canal 6, 2015.

D'ÁVILA, N. R. Semiótica Sincrética Aplicada: novas tendências. [org.]. São Paulo: Arte e Ciência, 2007.

DOLZ, J. NOVERRAZ M. SCHNEUWLY, B. Sequências didáticas para o oral e a escrita: apresentação de um procedimento. In: DOLZ J. SCHNEUWLY, B. Trad. e org. ROJO, R. CORDEIRO, G.S. Gêneros orais e escritos na escola. Mercado das Letras: São Paulo, 2004.

EISNER, W. Comics \& sequential art. Martins Fontes, 1999.

FIORIN, J. L. Elementos de Análise do Discurso. 15 ed. Ática, São Paulo, 2014

FLAVELL, J. H. Metacognitive aspects of problem solving. In L. B. Resnick (Ed.), The nat ure of int elligence, Hillsdale, NJ: Erlbaum. 1976, P. 231-235.

FLAVELL, J. H. Metacognitive development and reading. In R. J. Spiro, B. C. Bruce, \& W. F. Brewer (Eds.), Theoretical issues in reading comprehension Hillsdale, NJ: Erlbaum, 1980, pp. 453-482.

FLAVELL, J. H. Speculations about the nature and development of metacognition. In: WEINERT, F.E. \& KLUWE, R.H. (Eds.), Metacognition, Motivation, and understanding. Hillside, $\mathrm{NJ}$ : Lawrence Erlbaum Associates. 1987, p. 21-29.

FLAVELL, J. H \& R., PRESSLEY, M., VAN METER, P., \& SCHUDER, T. A quasiexperimental validation of transactional strategies instruction with lowachieving second-grade readers. Journal of Educational Psychology, 1996, p. 88, 18-37.

FLA VELL, J. H \& R., PRESSLEY, M., VAN METER, P., \& SCHUDER, T. Metacognition and cognitive monitoring: $A$ new area of cognitve-developmental inquiry. American Psychologist, 1979. pp. 906-911. 
FLAVELL, J. H \& R., PRESSLEY, M., VAN METER, P., \& SCHUDER, T. Cognitive Development. Stanford University. Prentice-Hall, Inc. Englewood Cliffs, New Jersey, 1985.

FLAVELL, J. H \& R., PRESSLEY, M., VAN METER, P., \& SCHUDER, T. The Development of Comprehension Monitoring and Knowledge about Communication. Monographs of the Society for Research in Child Development, Serial No. 192, Vol. 46, No. 5 by Flavell with SPEER, J. R., GREEN, F.L. AUGUST. 1981.

FLAVELL, J. H. \& WELLMAN, H. M. Metamemory. Em R. V. Kail \& J. W. Hagen (Orgs.), Perspetives on the development of memory and cognition. 1977. pp. 3-33. Hillsdale, N.J.: Erlbaum.

FOGARTY, R. Teach for Metacognitive Reflection. The Mindful School. IRI/ Skylight Publishing, Inc. Palatine, Illinois, 1994.

GREIMAS, A. J.; COURTÉS, J. Dicionário de Semiótica. 2 ed. Editora Contexto, 1979.

GREIMAS, A. J.; COURTÉS, J. A. J.; COURTÉS, J. Dicionário de Semiótica. 2 ed. Editora Contexto, 2013.

HIRSCH JR, E.D., KETT, J.F \& TREFIL, J. The Dictionary of Cultural Literacy. What Every American Needs to Know. $2^{\text {nd }}$ Edition, Revised and Updated. Houghton Mifflin Company, Boston, New York, 1993.

KOCH, I. G. V. As tramas do texto. 2 ed. São Paulo: Contexto, 2014.

KREUTZER, M. A., LEONARD, C., \& FLAVELL, J. H. An interview study of children's knowledge about memory. Monographs of the Society for Research in Child Development, 1975, 40(1, Serial No. 159).

LOGMAN, Dictionary of English Language and Culture. Longman Group UK Limited, Longman House, Burnt Mill, Harlow, Essex, England, 1992.

LOPES, I. C. HERNANDES, N. (orgs) Semiótica objetos e práticas. 2 ed. São Paulo: Contexto, 2013.

MARCUSCHI, L. A. Da fala para a escrita: atividades de retextualização. 10 ed. São Paulo: Cortez, 2010.

MENDONÇA, M. R. de S. Um gênero quadro a quadro: a história em quadrinhos. In: DIONISIO, A. P.; MACHADO, A. R;. BEZARRA, M. A. (org.) Gêneros textuais e ensino. São Paulo: Parábola, 2010.

PALINCSAR, A. M. S. \& BROWN, A. L. Reciprocal Teaching of Comprehension Fostering and Comprehension Monitoring Activities. In: Cognition and instruction, 1984, I (2) 117-175 Copyright o 1984, Lawrence Erlbaum Associates, Inc.

PRESSLEY, M. The relevance of good strategy user model to the teaching of mathematics. Educational Psychologist. V. 21, 1986. p. 139-161. 
RUIZ, E. D. Como corrigir redações na escola. 1 ed. 3 reimp. São Paulo: Contexto, 2015.

SANTOS, V. Semiótica e a formação de professores de português e literatura de Três Lagoas. In: SIMPOSIO INTERNACIONAL DO ENSINO DE LÍNGUA PORTUGUESA, UBERLÂNDIA, 2014, Uberlândia, EDUFU. Anais do SIELP, Vol. 3, n 1. Uberlândia: Universidade Federal de Uberlândia, 2014. ISSN: 2237-8758.

SANTOS, $V$. Identidade x Alteridade em "Flor de Aguapé", de Walmir Pacheco, na teoria greimasiana. In: D'Á VILA, N. R. (Org.). Semiótica verbal e sincrética, verbo-visual e verbo-musical - teorias e aplicabilidade. Bauru, São Paulo: Canal6, 2015. p. 83-115.

SANTOS, $\vee$. Na interface das estratégias de leitura instrumental e a leitura crítica: Reflexões e Sugestões. Diálogos Pertinentes, Franca, 2013.

SAVIOLI, F. P. FIORIN, J. L. F. Para entender o texto: leitura e redação. 17 ed. São Paulo: Ática, 2007.

SERAFINI, M. T. Como escrever textos. Trad. Maria Augusta Bastos de Mattos. São Paulo: Globo, 1989.

SOLÉ, I. Estratégias de leitura. 6 ed. Porto Alegre: Artmed, 1998.

VIGOTSKY, L.S. Pensamento e Linguagem. São Paulo, Martins Fontes, 1987.

VIGOTSKY, L.S. A formação social da mente. São Paulo: Martins Fontes, 1998.

Recebido em: Janeiro de 2017 Aceito em: Junho de 2017 